\title{
AIR POLLUTION BACKGROUND STUDY IN BOUBYAN ISLAND OF KUWAIT
}

\author{
H. TANG \& A. AL-DOUSARI \\ Environmental and Urban Development Division, Kuwait Institute for Scientific Research, Kuwait.
}

\section{ABSTRACT}

Boubyan Island is the largest island in Kuwait. It is an underdeveloped area. In order to prepare a master plan with a long range of resource management policies, Kuwait Institute for Scientific Research is involved in carrying out Boubyan field verification research studies and providing input to the preparation of a master plan. An all-season passive air sampling system for sampling $\mathrm{SO}_{2}, \mathrm{NO}_{\mathrm{x}}, \mathrm{O}_{3}$ and $\mathrm{H}_{2} \mathrm{~S}$ in the atmosphere was used in the air pollution background study in the island. This paper details the study results.

Keywords: air pollution, background study, passive sampling system.

\section{INTRODUCTION}

Boubyan Island is the largest island in Kuwait. It is an underdeveloped area. In order to prepare a master plan with a long range of resource management policies, Kuwait Institute for Scientific Research (KISR) is involved in carrying out Boubyan field verification research studies and providing input to the preparation of a master plan. One of the main objectives of this study is to assess the environmental conditions including air pollution of the island.

Boubyan Island covers an area of about $1,200 \mathrm{~km}^{2}$ (about $7 \%$ of Kuwait). The island is separated from the mainland (to its west) by Khor As Subiyah (maximum $3 \mathrm{~km}$ wide). It is bordered with Khor Boubyan (1.5-2 km wide) in the north and with Khor Abdullah in the east $(3 \mathrm{~km}$ wide in Kuwaiti territorial waters). There is no commercial power supply in the island except for several diesel engine power generators. The southern fringe of Boubyan Island overlooks the Arabian Gulf. Muddy beaches (about $2 \mathrm{~km}$ wide) are found in the eastern and southern coasts of the island.

Morphologically, the island is subdivided into three major areas: swamps/estuaries (about $40 \%$ of the island) in the northern part, wet and soft soil area in the southern part and semi-dry area in the central part. Besides these areas, a net of hydrographic basins is found in the island. Generally, the morphology of the island changes during different seasons. The surface sediment of Boubyan Island is composed of distinctly laminated and thinly bedded layers of aeolian silts and sandy to silty cohesive clay. The upper part is dominated by gypsum precipitation.

During summer, aeolian processes, which are represented by deflation, prevail at the central and southern parts of the island as a direct result of the following factors:

- the drop of the shallow groundwater table, which results in the dryness of the topsoil (silt and clay of high potential erodibility);

- prevailing strong northwesterly winds.

Aeolian landforms have a limited geographical extent in the island and they are represented by salty sheets, nabkhas (around halophytes) and gypsum dunes.

Currently, there are no artificial sources for air pollution in Boubyan Island. However, outside sources of air pollution from nearby areas, such as Um Qasr harbour, are of high potential.

Very scanty information is available on the environmental setting of Boubyan Island. KISR is proposing to conduct a baseline study for environmental conditions in Boubyan Island in order to provide information for the future development. 
An all-season passive air sample system (ASPASS) and a mobile station equipped with meteorological measurement devices were included in the network. $\mathrm{SO}_{2}, \mathrm{H}_{2} \mathrm{~S}, \mathrm{NO}_{\mathrm{x}}$ and $\mathrm{O}_{3}$ were monitored by the ASPASS. The sampling rates of the passive samplers were calculated using equations, which take into account their dependence on associated meteorological factors. The mobile station provided meteorological data for part of the network around the Boubyan Island seashore. Meteorological data on the inland of Boubyan Island were provided by another meteorological station located in the centre of the island.

\section{AIR POLLUTION MEASUREMENTS IN BOUBYAN}

Over the past few decades, many methods for monitoring air pollution in air have been developed and subsequently improved. These methods can generally be classified as active and passive methods [1-4].

Active methods directly pump air through collection devices to collect air pollutants. Therefore, electrical power is at least required to operate the active devices. A passive (or diffusive) sampler is a device which is capable of taking samples of gas or vapour pollutants from the atmosphere at a rate controlled by a physical process such as diffusion through a static air layer or permeation through a membrane. However, it does not involve the active movement of air through the sampler. Passive samplers are generally simple in structure and do not require electricity. Therefore, passive samplers are cost effective and convenient to use, especially for large networks.

The major difference between active samplers and passive samplers is that the active sampler has a known sampling rate, which is the pump's flow rate. The passive sampler's sampling rate depends on many factors such as temperature, relative humidity (RH), wind direction, wind speed, sampler's structure, collection media, etc. If a passive sampler is to be used in all climatic conditions, there must be a reasonable way to calculate the sampling rate. It would be highly unreasonable to expect that a passive sampler's sampling rate would not vary from $-30^{\circ} \mathrm{C}$ to $+50^{\circ} \mathrm{C}$. Therefore, the key factor for using passive samplers is to determine their sampling rates.

The principle of operation of passive samplers is based on Fick's first law of diffusion [5].

$$
\mathrm{J}=-\mathrm{DA} \frac{\mathrm{dc}}{\mathrm{dx}}
$$

where

$\mathrm{J}=$ diffusion transfer rate,

$\mathrm{D}=$ diffusion coefficient,

$\mathrm{A}=$ effective cross-sectional area,

$\mathrm{x}=$ distance along the diffusion path,

$\mathrm{c}=$ analyte concentration at a distance $\mathrm{x}$.

The negative sign in eqn (1) indicates that the concentration of the analyte decreases in the direction of diffusion.

Equation (1) can be simplified as shown in eqn (2):

$$
\mathrm{Q}=\mathrm{R}_{\mathrm{s}} \mathrm{C}_{\mathrm{e}} \mathrm{t},
$$

where

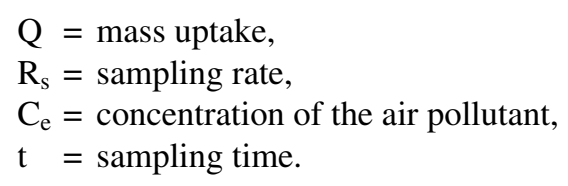


2.1 All-season passive sampling technology

An ASPASS for sampling $\mathrm{SO}_{2}, \mathrm{NO}_{\mathrm{x}}, \mathrm{O}_{3}$ and $\mathrm{H}_{2} \mathrm{~S}$ in the atmosphere, which has been developed by Dr. Hongmao Tang et al. [6-9] was used in this study. The ASPASS is shown in Fig. 1. The unique features of the ASPASS are:

- A new passive sampler body and a rain shelter were designed allowing the passive sampler to be installed face downwards outdoors. This design helps the PASS avoid dust problems and facilitates air movement parallel to the diffusion barrier surface (Figs 2 and 3).

- An equation, which accounts for variations in temperature, relative humidity and wind speed, is used to calculate sampling rates.

- The ASPASS is very sensitive. It can be used to collect ppt levels of $\mathrm{H}_{2} \mathrm{~S}$ and sub ppb levels of $\mathrm{SO}_{2}$ and $\mathrm{O}_{3}$ in air.

- The collection time is very flexible. It can be exposed from four hours up to six months depending on the monitored pollutant and its average concentration in air.

The ASPASS has been validated in many countries. During validation, the temperature ranged from $-40^{\circ} \mathrm{C}$ to $35^{\circ} \mathrm{C}$ and the relative humidity from $30 \%$ to $100 \%$. The exposure times ranged from

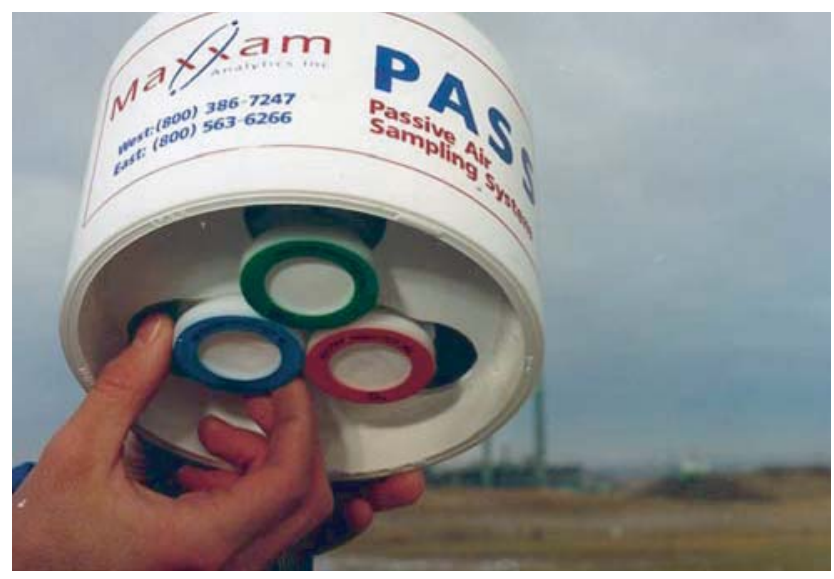

Figure 1: The all-season passive air sampling system.

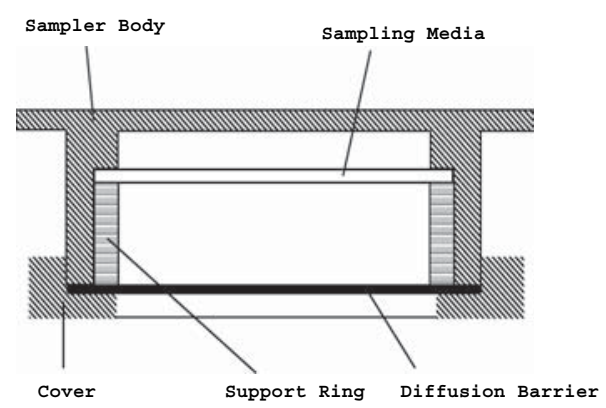

Figure 2: Schematic representation of the ASPASS passive sampler. 


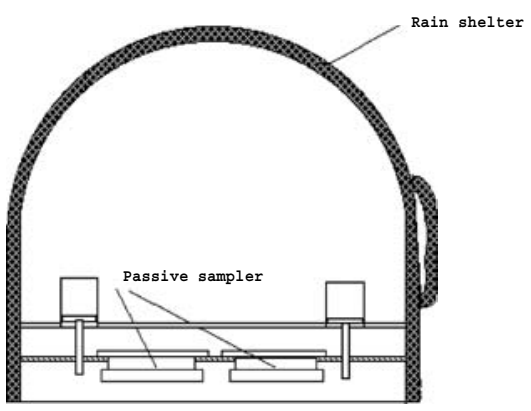

Figure 3: Schematic representation of the ASPASS rain shelter.

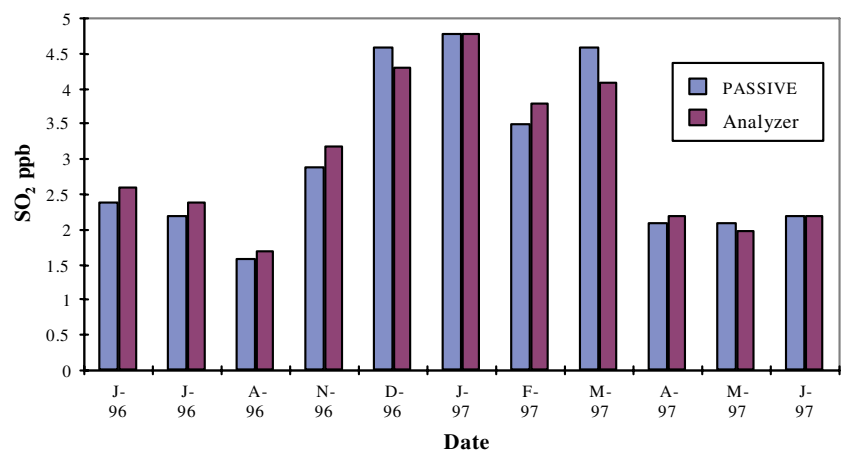

Figure 4: Four-season comparison of $\mathrm{SO}_{2}$ concentrations obtained by the passive sampling technology and an $\mathrm{SO}_{2}$ analyser.

two days to three months. The correlation between the ASPASS and an $\mathrm{SO}_{2}, \mathrm{O}_{3}$ or $\mathrm{H}_{2} \mathrm{~S}$ continuous analyser is very good.

Figure 4 shows a whole year of study results of ASPASS for $\mathrm{SO}_{2}$ passive samplers conducted at a Canadian air-monitoring station from June 1996 to June 1997. During the study period, the temperatures ranged from $-40^{\circ} \mathrm{C}$ to $35^{\circ} \mathrm{C}$, the $\mathrm{RH}$ from $30 \%$ to $100 \%$ and the wind speed $>130 \mathrm{~cm} / \mathrm{s}$. It can be observed that the correlation between the PASS for $\mathrm{SO}_{2}$ and the $\mathrm{SO}_{2}$ continuous analysers was excellent.

The Alberta Research Council (ARC) supported by the National Research Council of Canada conducted an independent validation of the ASPASS for $\mathrm{SO}_{2}$ in 1998 [10]. Table 1 lists the locations, validation periods and $\mathrm{SO}_{2}$ concentrations measured by the passive samplers and monitored by the continuous analysers and the relative errors in each study.

The ASPASS has been used in 17 countries in the world (Fig. 5) [11-14].

Figure 6 is an example of the application of ASPASS. The Parkland Airshed Management Zone Association (PAMZ) in Canada was formed under the umbrella of the Clean Air Strategic Alliance adopting their principles and guidelines. The society is an independent entity that provides ongoing progress updates to the alliance [11]. The PAMZ has been using the ASPASS for monitoring air pollution since 1998. Figure 6 clearly shows the $\mathrm{SO}_{2}$ concentration distributions in the network. The right site of Fig. 6 is the background location. The $\mathrm{SO}_{2}$ concentrations were less than $1 \mathrm{ppb}$. 
Table 1: Independent ARC validation of PASS for $\mathrm{SO}_{2}$ using a passive sampler.

\begin{tabular}{llccc}
\hline Location & \multicolumn{1}{c}{ Exposure date } & Passive (ppb) & Analyser (ppb) & Error (\%) \\
\hline TMK & 31 July-28 August & 1.3 & 1.4 & 7 \\
TMK & 1 November-3 December & 1.6 & 1.6 & 0 \\
EIMU & 31 July-28 August & 1.8 & 2.0 & 10 \\
EIMU & 1 November-3 December & 3.0 & 3.2 & 6 \\
\hline
\end{tabular}

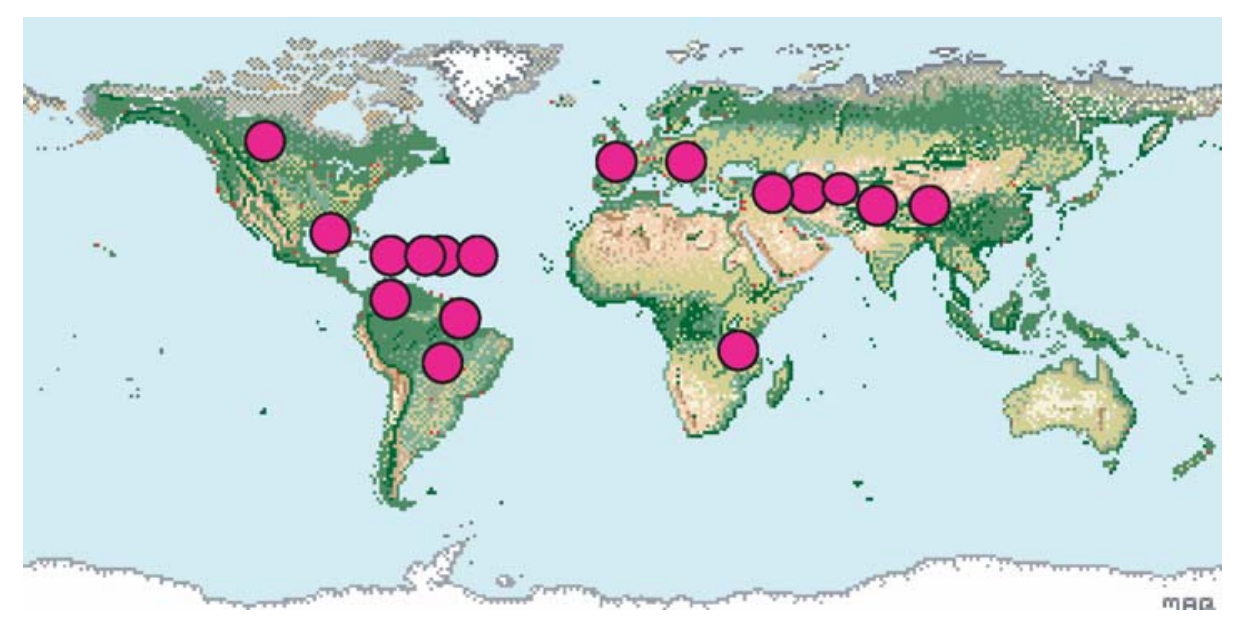

Figure 5: ASPASS application in the world.

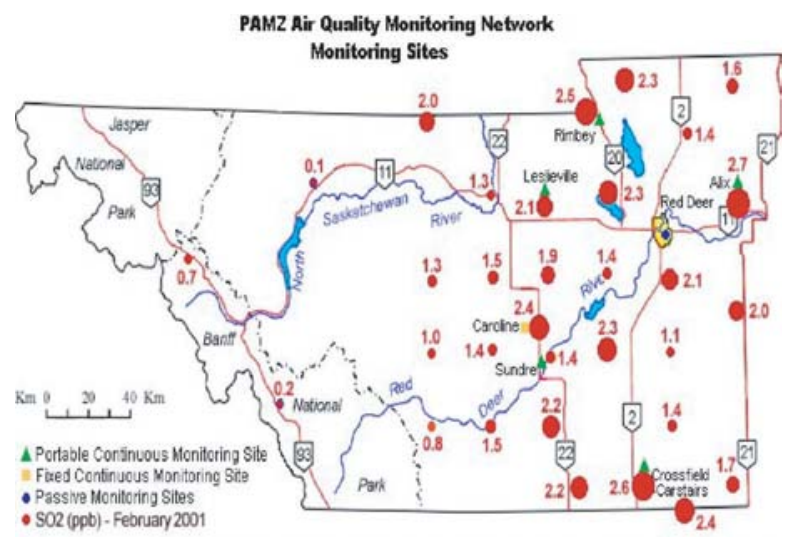

Figure 6: Measurement of $\mathrm{SO}_{2}$ distributions in PAMZ by ASPASS in February 2001. 
Table 2: Comparison of the results of the ASPASS and the analysers in Kuwait.

\begin{tabular}{lcccc}
\hline Pollutant & Exposure date & Passive $(\mathrm{ppb})$ & Analyser $(\mathrm{ppb})$ & Error (\%) \\
\hline $\mathrm{NO}_{\mathrm{x}}$ & 11-18 August 2004 & 25.0 & 27 & 7 \\
$\mathrm{O}_{3}$ & 11-18 August 2004 & 41.6 & 39.7 & 4 \\
$\mathrm{SO}_{2}$ & 20-27 October 2004 & 11.7 & 11.1 & 5 \\
$\mathrm{H}_{2} \mathrm{~S}$ & 20-27 October 2004 & 3.4 & 3.1 & 10 \\
\hline
\end{tabular}

The ASPASS was validated in Kuwait in 2004. Kuwait has a desert climatic condition that is hot and dry. In summer, the temperature can reach to about $50^{\circ} \mathrm{C}$ and is totally different from Canada's weather condition, which is relatively cold. It was a good opportunity to test the ASPASS's ability in an extremely hot climatic condition. During validation, the ASPASS results were compared with that of different air pollution analysers. Table 2 lists the comparison results. It can be seen that the comparison results are very encouraging. The $\mathrm{NO}_{\mathrm{x}}$ passive sampling has not been completely developed in Canada, but its continuous development in Kuwait has made this passive sampler more useful.

\subsection{Boubyan air-monitoring network}

Air-monitoring network is a typical way to study air pollution in a large area. The very important feature of an air pollution monitoring network is that it can create same-period air pollution concentrations for different locations and provide useful information for air quality management. Therefore, air pollution-monitoring networks have been widely used in the world.

There are many priorities for designing an air pollution-monitoring network. The design of the air monitoring network in Boubyan was based on the major concern of determining the air quality background levels in given locations.

The basic network location selection is grid and radial. We utilised a combination of grid and radial network location selection in the Boubyan network. Due to geographical conditions, it is not so easy to reach some areas and therefore accessibility has to be taken into consideration.

\subsection{Passive sampling site selection}

A total of 16 passive sampling stations were selected in the network (Fig. 7) with 14 stations in Boubyan, and 2 in Walbah. The distance between any two stations was about $5 \mathrm{~km}$. The passive station site selection was based on the need of the network study. Uniform siting criteria are necessary to ensure the collection of compatible and comparable data. The following criteria are adopted for this study.

- Monitoring sites should not be located near pollution sources.

- Monitoring sites should not be close to roadways. The distance between the site and the roadway should be more than $10 \mathrm{~m}$.

- The preferred site is flat, non-representative valley locations and siting at the top or the base of a hill, unless special studies are needed for these locations and weather information can be obtained.

The 16 passive station locations are listed in Table 3 (also see Fig. 7). Figures 8 and 9 show stations 11 and 15 , respectively. 


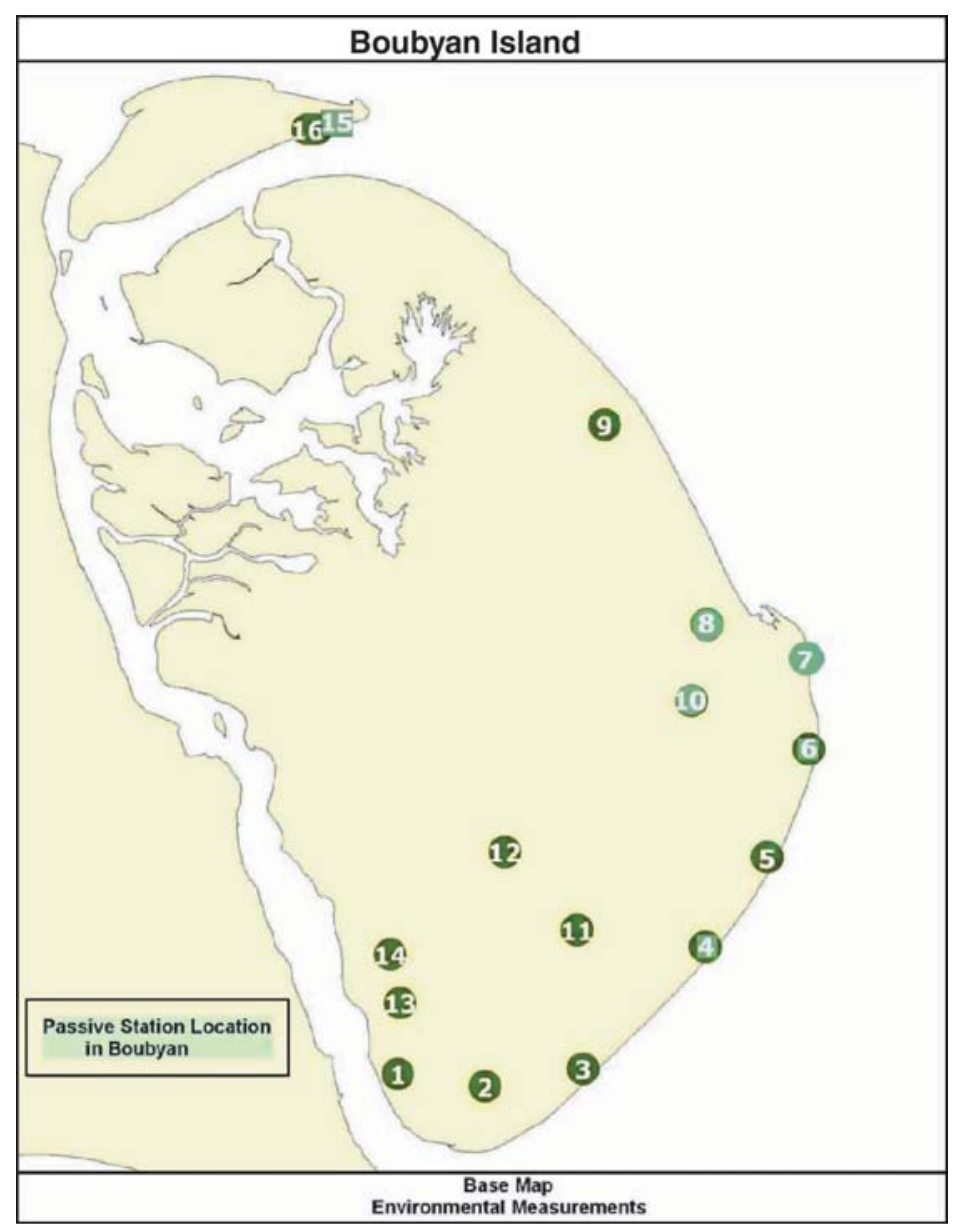

Figure 7: Passive air-monitoring network in Boubyan.

\subsection{Installation of ASPASS}

For credible results, it is recommended that at least duplicate passive samplers in several stations be used. In this study, duplicate passive samplers were used in stations 7 and 15 . To validate the results, field blanks were also included. The passive samplers were installed in a rain shelter (Fig. 1). Each passive sampler was installed in the rain shelter face downward. Holding the bottom of the passive sampler and on pushing up any one of the three buttons in the rain shelter, the passive sampler could easily be slid into the centre of the rain shelter. The installation height of the rain shelter followed the standard site criteria of Alberta Environmental Protection Services [15] (Fig. 10):

- the rain shelter should be $1-3 \mathrm{~m}$ above the ground;

- the elevation angle should be $<30^{\circ}$ from the diffusion barrier surface of the passive sampler to the top of any object;

- the distance from the object to the rain shelter should be $>10$ times the height of the object. 
Table 3: Locations of the passive stations in Boubyan.

\begin{tabular}{ccc}
\hline Station & $\mathrm{N}$ & $\mathrm{E}$ \\
\hline 1 & $29^{\circ} 36^{\prime} 46.1^{\prime \prime}$ & $48^{\circ} 11^{\prime} 00.0^{\prime \prime}$ \\
2 & $29^{\circ} 36^{\prime} 30.7^{\prime \prime}$ & $48^{\circ} 13^{\prime} 29.5^{\prime \prime}$ \\
3 & $29^{\circ} 37^{\prime} 00.5^{\prime \prime}$ & $48^{\circ} 16^{\prime} 14.9^{\prime \prime}$ \\
4 & $29^{\circ} 42^{\prime} 21.5^{\prime \prime}$ & $48^{\circ} 21^{\prime} 20.6^{\prime \prime}$ \\
5 & $29^{\circ} 45^{\prime} 03.2^{\prime \prime}$ & $48^{\circ} 22^{\prime} 27.0^{\prime \prime}$ \\
6 & $29^{\circ} 40^{\prime} 05.3^{\prime \prime}$ & $48^{\circ} 19^{\prime} 39.2^{\prime \prime}$ \\
7 & $29^{\circ} 46^{\prime} 11.2^{\prime \prime}$ & $48^{\circ} 19^{\prime} 05.1^{\prime \prime}$ \\
8 & $29^{\circ} 47^{\prime} 19.3^{\prime \prime}$ & $48^{\circ} 22^{\prime} 18.9^{\prime \prime}$ \\
9 & $29^{\circ} 52^{\prime} 56.9^{\prime \prime}$ & $48^{\circ} 16^{\prime} 25^{\prime \prime}$ \\
10 & $29^{\circ} 48^{\prime} 5^{\prime \prime}$ & $48^{\circ} 19^{\prime} 29.1^{\prime \prime}$ \\
11 & $29^{\circ} 40^{\prime} 25.7^{\prime \prime}$ & $48^{\circ} 15^{\prime} 59.7^{\prime \prime}$ \\
12 & $29^{\circ} 42^{\prime} 20.5^{\prime \prime}$ & $48^{\circ} 13^{\prime} 53.6^{\prime \prime}$ \\
13 & $29^{\circ} 39^{\prime} 43.2^{\prime \prime}$ & $48^{\circ} 10^{\prime} 42.6^{\prime \prime}$ \\
14 & $29^{\circ} 38^{\prime} 31.5^{\prime \prime}$ & $48^{\circ} 11^{\prime} 01.5^{\prime \prime}$ \\
15 & $30^{\circ} 00^{\prime} 06.3^{\prime \prime}$ & $48^{\circ} 08^{\prime} 00.7^{\prime \prime}$ \\
16 & $30^{\circ} 00^{\prime} 06.3^{\prime \prime}$ & $48^{\circ} 07^{\prime} 46.1^{\prime \prime}$ \\
\hline
\end{tabular}

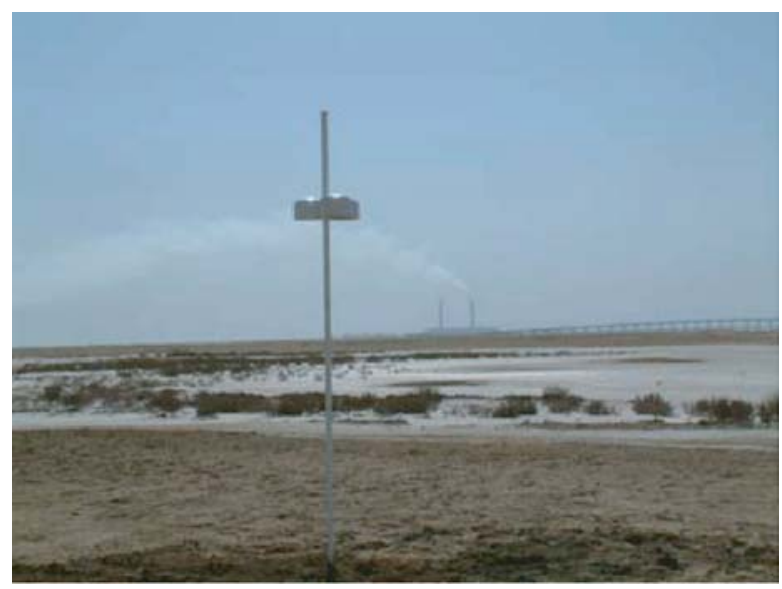

Figure 8: Passive station 11 in Boubyan.

In general, the rain shelter must be installed properly to prevent passive samplers from being tampered with by animals, human beings or the surroundings. The exposure start and end times and date of the passive samplers were recorded on a field-sampling sheet. The average temperature, average relative humidity and average wind speed during the exposure period were obtained from the local weather station.

After exposure, the collection media in the passive samplers were analysed in a laboratory equipped with ion chromatography, fluorometry and colorimetric devices. 


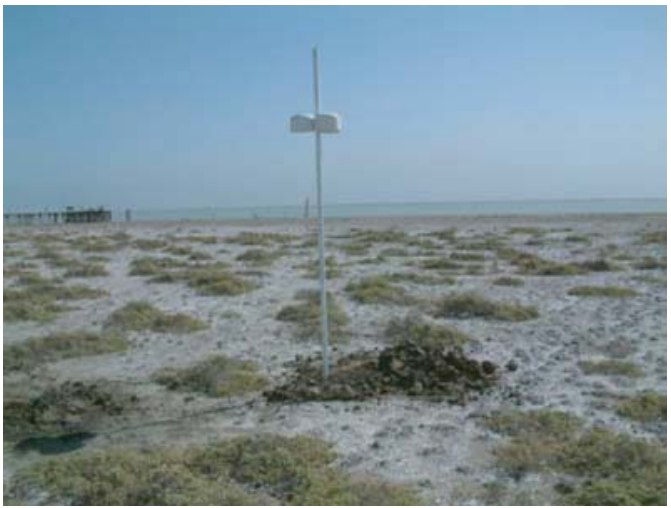

Figure 9: Passive station 15 in Walbah.

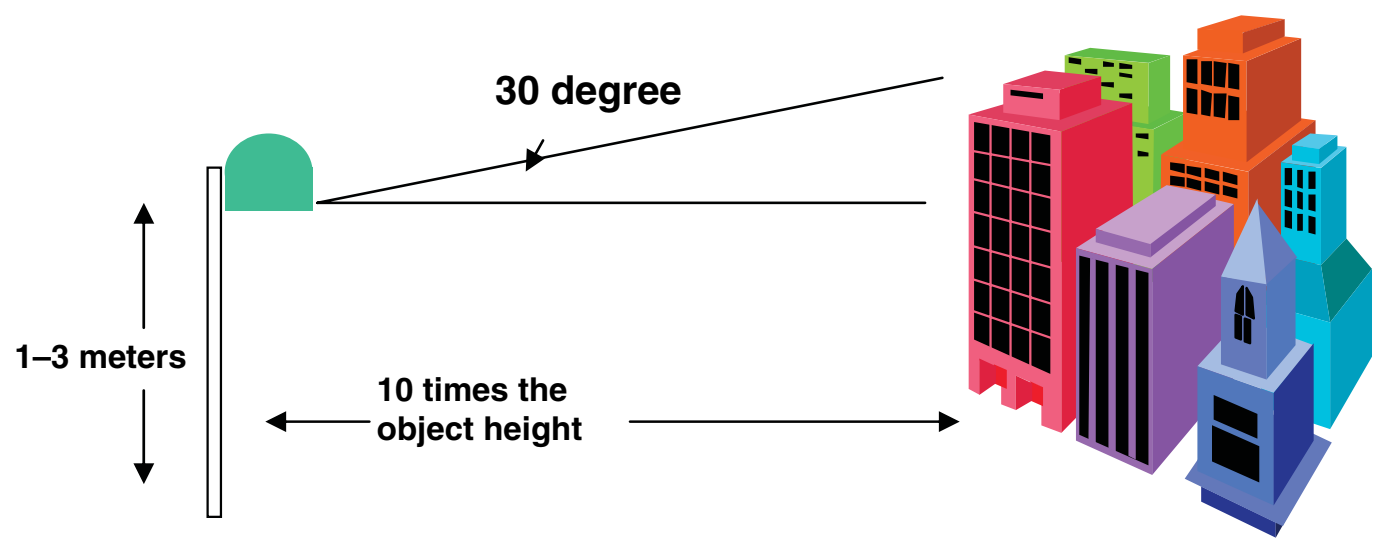

Figure 10: Passive sampler station installation height and distance.

\section{RESULTS AND DISCUSSION}

The summarised measurement results for nine months, from July 2004 to March 2005, are shown in Tables 2-5. Unfortunately, there are no results for some stations due to instrument problems in the lab, or samples lost or damaged in the field, which is indicated as NA. We also include wind roses for August and September 2004 (Figs 11 and 12) in order to interpret the sulphur dioxide differences.

From Tables 4 to 7, generally speaking, it can be observed that the monthly air pollution concentration distributions in the Boubyan network were different from station to station and from month to month. This is because air pollution concentrations are affected by meteorological conditions (especially wind directions) and local micro-environments. For example, from Table 4, it can be found that the $\mathrm{SO}_{2}$ concentrations in September were higher than those in August. On reading the wind directions from Figs 11 and 12, it can be seen that there were more western winds in September than in August. The western winds blew the $\mathrm{SO}_{2}$ generated by the thermal power station into the island (Fig. 8).

Since the ASPASS has been well validated in many countries including Kuwait, as mentioned in Section 2.4, duplicate passive samplers were used in stations 7 and 15 to control the study. Table 8 lists 
Table 4: Sulphur dioxide air pollution concentrations in Boubyan network.

\begin{tabular}{lccccccccr}
\hline $\begin{array}{l}\text { Station } \\
\text { no. }\end{array}$ & $\begin{array}{c}4 \\
\text { July }\end{array}$ & $\begin{array}{c}4 \\
\text { August }\end{array}$ & $\begin{array}{c}4 \\
\text { September }\end{array}$ & $\begin{array}{c}4 \\
\text { October }\end{array}$ & $\begin{array}{c}4 \\
\text { November }\end{array}$ & $\begin{array}{c}4 \\
\text { December }\end{array}$ & $\begin{array}{c}5 \\
\text { January }\end{array}$ & $\begin{array}{c}5 \\
\text { February }\end{array}$ & $\begin{array}{c}5 \\
\text { March }\end{array}$ \\
\hline 1 & NA & 2.3 & 12.6 & 6.1 & 3.9 & 3.9 & 1.7 & 1.7 & 8.0 \\
2 & 4.8 & 1.5 & 6.8 & 5.0 & 3.1 & 3.1 & 2.0 & 2.0 & 10.9 \\
3 & 4.3 & 1.4 & 3.3 & 2.4 & 3.4 & 3.4 & 1.9 & 1.9 & 5.7 \\
4 & 3.3 & 2.1 & 5.8 & 2.8 & 3.2 & 3.2 & 1.8 & 1.8 & 5.0 \\
5 & NA & 2.0 & 2.5 & 3.8 & 3.1 & 3.1 & 1.5 & 1.5 & NA \\
6 & 4.5 & 1.5 & 4.5 & 2.5 & 2.7 & 2.7 & 1.8 & 1.8 & 8.4 \\
7 & 3.3 & 2.0 & 4.0 & 2.7 & 2.8 & 2.8 & 1.9 & 1.9 & 7.6 \\
8 & 5.1 & 2.1 & 7.4 & 4.5 & 3.1 & 3.1 & 1.9 & 1.9 & 9.3 \\
9 & 3.1 & 2.4 & 5.2 & 4.4 & 3.6 & 3.6 & 2.0 & 2.0 & 11.9 \\
10 & 4.4 & 2.0 & 9.4 & 3.8 & NA & NA & NA & NA & NA \\
11 & 5.8 & 1.7 & 6.3 & 5.1 & 2.7 & 2.7 & 1.8 & 1.8 & 8.0 \\
12 & 5.5 & 2.0 & 10.2 & 4.6 & 2.7 & 2.7 & 2.1 & 2.1 & NA \\
13 & 6.3 & 1.9 & 12.4 & 5.1 & 3.4 & 3.4 & 2.2 & 2.2 & NA \\
14 & 4.6 & 1.5 & 8.2 & 5.6 & 3.1 & 3.1 & 2.3 & 2.3 & 7 \\
15 & 2.9 & 2.1 & 4.5 & 3.2 & NA & NA & 5.1 & 5.1 & 8.2 \\
16 & 4.2 & 3.1 & 9.1 & 8.8 & NA & NA & 3.3 & 3.3 & 16.0 \\
Average & 4.4 & 2.0 & 7.0 & 4.4 & 3.2 & 3.2 & 2.2 & 2.2 & 8.8 \\
\hline
\end{tabular}

Table 5: Hydrogen sulphide air pollution concentrations in Boubyan network.

\begin{tabular}{lccccccccc}
\hline $\begin{array}{l}\text { Station } \\
\text { no. }\end{array}$ & $\begin{array}{c}4 \\
\text { July }\end{array}$ & $\begin{array}{c}4 \\
\text { August }\end{array}$ & $\begin{array}{c}4 \\
\text { September }\end{array}$ & $\begin{array}{c}4 \\
\text { October }\end{array}$ & $\begin{array}{c}4 \\
\text { November }\end{array}$ & $\begin{array}{c}4 \\
\text { December }\end{array}$ & $\begin{array}{c}5 \\
\text { January }\end{array}$ & $\begin{array}{c}5 \\
\text { February }\end{array}$ & $\begin{array}{c}5 \\
\text { March }\end{array}$ \\
\hline 1 & 0.79 & 0.79 & 1.86 & NA & 0.43 & 0.43 & 0.55 & 0.31 & 0.39 \\
2 & 0.69 & 0.69 & 1.46 & NA & 0.92 & 0.92 & 0.28 & 0.22 & 0.41 \\
3 & NA & NA & 1.66 & NA & 0.58 & 0.58 & 0.40 & 0.22 & 0.40 \\
4 & 0.38 & 0.38 & 1.46 & NA & 0.99 & 0.99 & 0.42 & 0.04 & 0.56 \\
5 & 0.31 & 0.31 & 6.17 & NA & 0.07 & 0.07 & 0.42 & 0.23 & 0.35 \\
6 & 0.57 & 0.57 & 3.16 & NA & 0.69 & 0.69 & 0.50 & 0.21 & 0.37 \\
7 & 1.42 & 1.42 & 3.43 & NA & 0.55 & 0.55 & 0.46 & 0.22 & 0.44 \\
8 & 0.53 & 0.53 & 4.41 & NA & 0.07 & 0.07 & 0.32 & 0.34 & 0.43 \\
9 & 0.85 & 0.85 & 3.95 & NA & 0.83 & 0.83 & 0.47 & 0.16 & 0.42 \\
10 & 0.61 & 0.61 & 5.39 & NA & NA & NA & NA & NA & 0.20 \\
11 & 0.53 & 0.53 & 5.52 & NA & 0.65 & 0.65 & 0.38 & 0.34 & 0.30 \\
12 & 0.63 & 0.63 & 4.34 & NA & 0.97 & 0.97 & 0.37 & 0.34 & 0.36 \\
13 & 0.32 & 0.32 & 4.54 & NA & 0.63 & 0.63 & 0.37 & 0.32 & 0.46 \\
14 & NA & NA & NA & NA & 0.90 & 0.90 & 0.44 & 0.22 & 0.42 \\
15 & 0.51 & 0.51 & 6.48 & NA & NA & NA & 0.45 & 0.38 & 0.35 \\
16 & 0.64 & 0.64 & 6.99 & NA & NA & NA & 0.43 & 0.33 & 0.35 \\
Average & 0.63 & 0.63 & 4.05 & NA & 0.64 & 0.64 & 0.42 & 0.26 & 0.39 \\
\hline
\end{tabular}

the duplicate results obtained in August. The duplicate results were very good. The relative errors ranged from $1 \%$ to $7 \%$.

The $\mathrm{SO}_{2}$ concentration distribution maps for August and September 2004 in Boubyan Island are shown in Figs 13 and 14. It can be clearly seen that the air pollution concentrations were different at different locations. Due to air pollution emission from the thermal power plant, the $\mathrm{SO}_{2}$ 


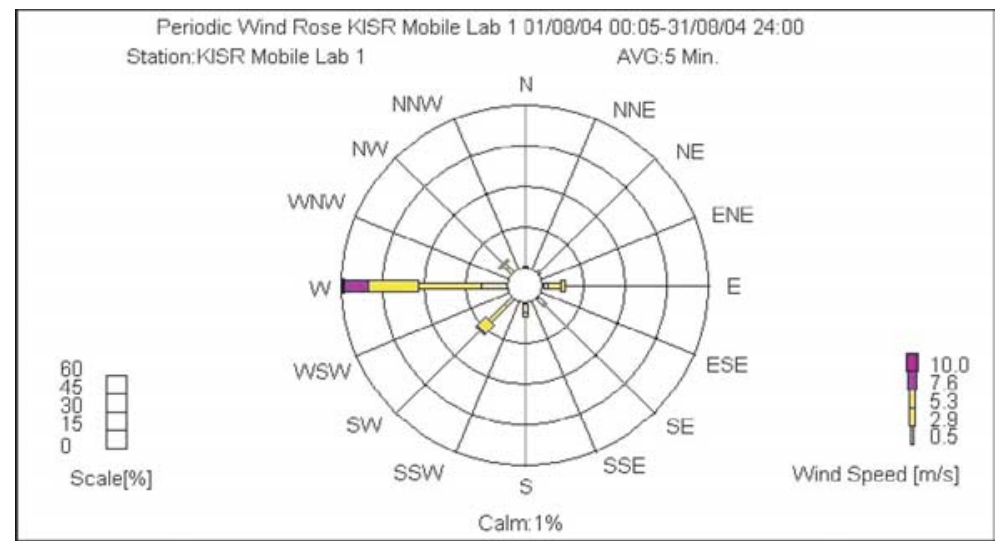

Figure 11: Wind rose for August 2004 (wind blew to).

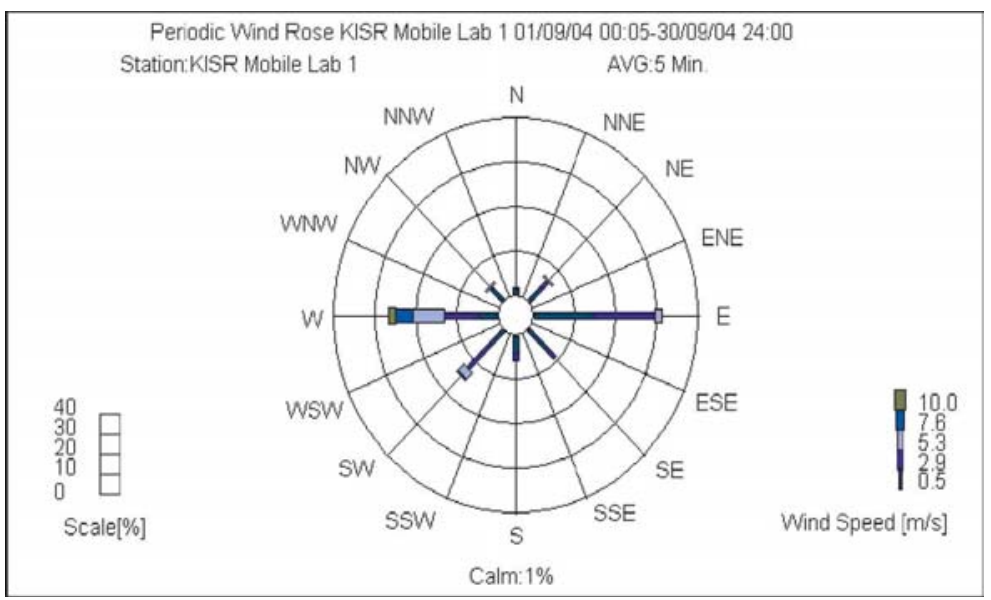

Figure 12: Wind rose for September 2004 (wind blew to).

concentrations, in September, in the stations close to the thermal power plant (such as Stations 1 and 13) were higher than those from other stations.

Figure 15 shows the monthly Boubyan Island average air pollution concentrations (average of the 16 stations) in the nine months' study period. It can be found that only ozone concentrations have a clear trend with low concentrations at low temperatures from November 2004 to February 2005. In Kuwait, the temperatures are lower, and solar UV radiations are less during these months. September 2004 was the worst month; all three primary air pollutants were higher. Although there is no clear trend for the other air pollutants in the nine months' period compared to ozone, Fig. 15 still shows that concentrations of $\mathrm{SO}_{2}$ and $\mathrm{NO}_{\mathrm{x}}$ decreased from November 2004 to February 2005, which indicates that air pollution transportations from other sources to the island might be slowed down due to lower temperatures.

Figure 16 shows the nine-month average air pollution concentrations at each station. In general, there is no significant concentration difference, which can be observed in the figure except 
Table 6: Nitrogen oxides air pollution concentrations in Boubyan network.

\begin{tabular}{lccccccccc}
\hline $\begin{array}{l}\text { Station } \\
\text { no. }\end{array}$ & $\begin{array}{c}4 \\
\text { July }\end{array}$ & $\begin{array}{c}4 \\
\text { August }\end{array}$ & $\begin{array}{c}4 \\
\text { September }\end{array}$ & $\begin{array}{c}4 \\
\text { October }\end{array}$ & $\begin{array}{c}4 \\
\text { November }\end{array}$ & $\begin{array}{c}4 \\
\text { December }\end{array}$ & $\begin{array}{c}5 \\
\text { January }\end{array}$ & $\begin{array}{c}5 \\
\text { February }\end{array}$ & $\begin{array}{c}5 \\
\text { March }\end{array}$ \\
\hline 1 & NA & NA & 4.9 & 2.9 & 3.0 & 3.0 & 3.2 & 2.6 & 4.0 \\
2 & NA & 2.8 & 4.6 & 3.1 & 2.8 & 2.8 & 3.4 & 2.2 & 3.3 \\
3 & NA & 3.0 & 4.6 & 2.9 & 2.9 & 2.9 & 2.8 & 2.8 & 2.9 \\
4 & NA & NA & 4.6 & 2.5 & 2.9 & 2.9 & 2.5 & 2.1 & 2.3 \\
5 & NA & 1.9 & 3.9 & 2.3 & 3.4 & 3.4 & 2.4 & 2.1 & 2.1 \\
6 & NA & 2.0 & 3.3 & 2.8 & 3.0 & 3.0 & 2.6 & 1.6 & 2.7 \\
7 & NA & 2.7 & 4.9 & 3.6 & 3.5 & 3.5 & 2.6 & 2.2 & 3.5 \\
8 & NA & NA & 3.4 & 2.2 & 3.0 & 3.0 & 2.6 & 2.1 & 2.1 \\
9 & NA & 1.5 & 2.6 & 2.8 & 3.6 & 3.6 & 2.5 & 2.6 & 2.9 \\
10 & NA & 1.4 & 3.4 & 2.1 & NA & NA & NA & NA & 3.5 \\
11 & NA & 1.7 & 3.6 & 2.4 & 3.4 & 3.4 & 2.7 & 2.1 & 2.9 \\
12 & NA & 1.6 & 3.3 & 2.4 & 3.3 & 3.3 & 2.5 & 2.2 & NA \\
13 & NA & 2.0 & 3.6 & 2.5 & 3.3 & 3.3 & 2.8 & 2.1 & 3.5 \\
14 & NA & 0.8 & 2.9 & 2.7 & 3.4 & 3.4 & 2.8 & 2.2 & 2.7 \\
15 & NA & 3.0 & 4.1 & 4.0 & NA & NA & 1.9 & 2.5 & 3.6 \\
16 & NA & 3.2 & 8.4 & 13.2 & NA & NA & 3.1 & NA & 11.5 \\
Average & NA & 2.1 & 4.2 & 3.4 & 3.2 & 3.2 & 2.7 & 2.2 & 3.3 \\
\hline
\end{tabular}

Table 7: Ozone air pollution concentrations in Boubyan network.

\begin{tabular}{lccccccccc}
\hline $\begin{array}{l}\text { Station } \\
\text { no. }\end{array}$ & $\begin{array}{c}4 \\
\text { July }\end{array}$ & $\begin{array}{c}4 \\
\text { August }\end{array}$ & $\begin{array}{c}4 \\
\text { September }\end{array}$ & $\begin{array}{c}4 \\
\text { October }\end{array}$ & $\begin{array}{c}4 \\
\text { November }\end{array}$ & $\begin{array}{c}4 \\
\text { December }\end{array}$ & $\begin{array}{c}5 \\
\text { January }\end{array}$ & $\begin{array}{c}5 \\
\text { February }\end{array}$ & $\begin{array}{c}5 \\
\text { March }\end{array}$ \\
\hline 1 & NA & 49.3 & 52.4 & 46.0 & 41.7 & 41.7 & 31.2 & 42.2 & 45.6 \\
2 & 58.7 & 50.9 & 62.6 & 50.0 & 39.9 & 39.9 & 26.2 & 44.9 & 54.6 \\
3 & 59.4 & 49.1 & 52.2 & 45.3 & 51.5 & 51.5 & 28.7 & 42.8 & 43.8 \\
4 & 70.1 & NA & 58.6 & 53.0 & 42.2 & 42.2 & 30.6 & 47.9 & 50.9 \\
5 & 63.7 & 53.3 & 49.5 & 44.6 & 42.6 & 42.6 & 32.5 & 41.4 & 45.2 \\
6 & NA & 45.0 & 65.9 & 47.0 & 41.8 & 41.8 & 31.4 & 42.8 & 61.8 \\
7 & 66.8 & 59.5 & 57.8 & 50.8 & 42.4 & 42.4 & 34.6 & 45.0 & 50.0 \\
8 & 51.0 & 53.7 & 85.7 & 42.9 & 40.7 & 40.7 & 31.3 & 50.3 & 56.5 \\
9 & 49.9 & 52.1 & 46.8 & 47.9 & 44.7 & 44.7 & 34.1 & 49.2 & 51.1 \\
10 & 45.1 & 54.1 & 49.7 & 44.3 & NA & NA & NA & NA & 43.9 \\
11 & 38.8 & 47.8 & 40.7 & 49.9 & 53.3 & 53.3 & 31.8 & 40.8 & 46.4 \\
12 & 42.5 & 51.3 & 55.9 & 39.3 & 40.0 & 40.0 & 30.2 & 40.4 & NA \\
13 & NA & 50.8 & 52.3 & 44.0 & 49.2 & 49.2 & 35.1 & 46.1 & 43.4 \\
14 & NA & 52.6 & 42.2 & 43.1 & 41.0 & 41.0 & 28.5 & 41.2 & 47.5 \\
15 & 43.8 & 50.8 & 48.7 & 46.0 & NA & NA & 36.0 & 40.6 & 43.0 \\
16 & NA & 48.3 & 42.1 & 50.7 & NA & NA & 34.0 & 31.0 & 47.0 \\
Average & 53.6 & 51.2 & 53.9 & 46.5 & 43.9 & 43.9 & 31.7 & 43.1 & 48.7 \\
\hline
\end{tabular}

for station 16, where $\mathrm{SO}_{2}$ and $\mathrm{NO}_{\mathrm{x}}$ concentrations were higher. On further investigation, we found that the higher $\mathrm{SO}_{2}$ and $\mathrm{NO}_{\mathrm{x}}$ concentrations were due to a diesel power generator close to the passive station. From Fig. 16, it can also be observed that $\mathrm{SO}_{2}$ concentrations in stations 3-7 were low compared to other stations. At this moment, we only found that geographically there were more dry lands in those locations than others. There might be other local micro $\mathrm{SO}_{2}$ sources, which cause the higher results. 
Table 8: Duplicate results of August in stations 7 and 15.

\begin{tabular}{lccccccc}
\hline & \multicolumn{3}{c}{ Station 7 $(\mathrm{ppb})$} & & \multicolumn{3}{c}{ Station 15 (ppb) } \\
\cline { 2 - 3 } \cline { 8 - 9 } Pollutant & Sampler 1 & Sampler 2 & Error \% & & Sampler 1 & Sampler 2 & Error \% \\
\hline $\mathrm{SO}_{2}$ & 2.0 & 1.9 & 3 & & 2.0 & 2.1 & 2 \\
$\mathrm{H}_{2} \mathrm{~S}$ & 1.41 & 1.44 & 1 & & 0.51 & 0.52 & 2 \\
$\mathrm{NO}_{x}$ & NA & NA & NA & & 2.8 & 3.2 & 7 \\
$\mathrm{O}_{3}$ & 56.7 & 59.5 & 2 & & 50.8 & 49.7 & 2 \\
\hline
\end{tabular}

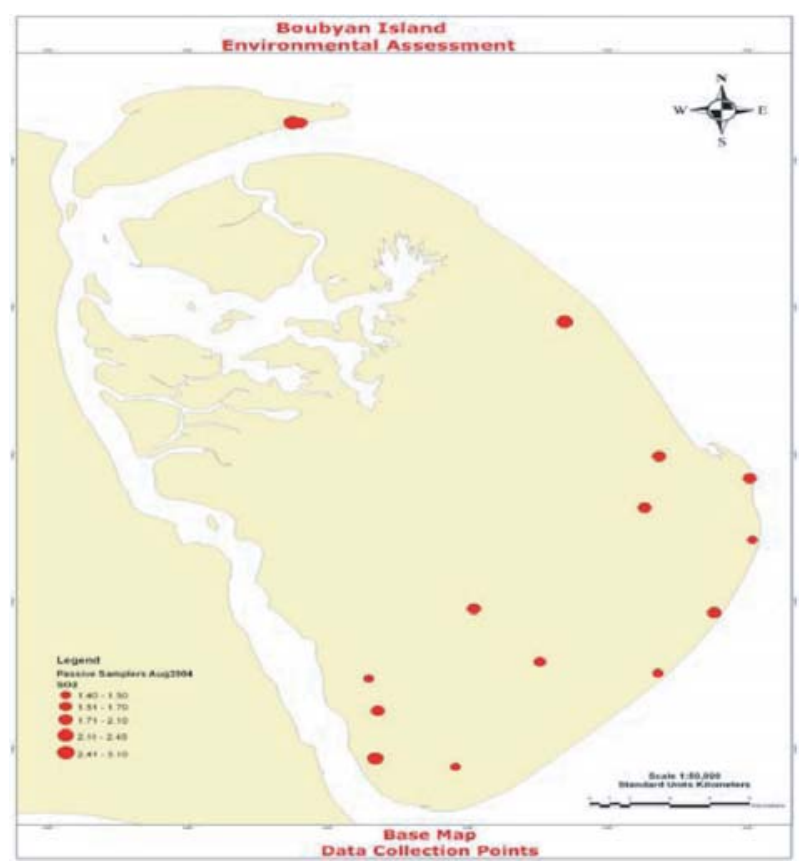

Figure 13: Air pollution concentration of $\mathrm{SO}_{2}$ for August 2004.

Table 9 lists the nine months' average concentrations of the four air pollutants for the whole network (16 stations). It can be seen that the air pollutants' concentrations in Boubyan are high compared to other background areas in the world. This indicates that the air quality in Boubyan is already affected by other polluted areas either from Kuwait or from other countries.

Kuwait is a small country. The air pollution transportation from industrial areas to the Boubyan Island will affect the island's air quality. In order to compare the air pollution levels in a Kuwait industrial area and Boubyan Island, we also installed a passive station in an industrial area (named STN 4). Figure 17 shows the concentration comparison results of a station in Boubyan Island (named Warba) and the station in an industrial area. It is not surprising to see that the industrial area air pollution levels, except ozone, are very high compared to that of the Boubyan Island. But the $\mathrm{SO}_{2}$ concentrations in Boubyan Island were much higher compared to those obtained in Canada (Fig. 6). 


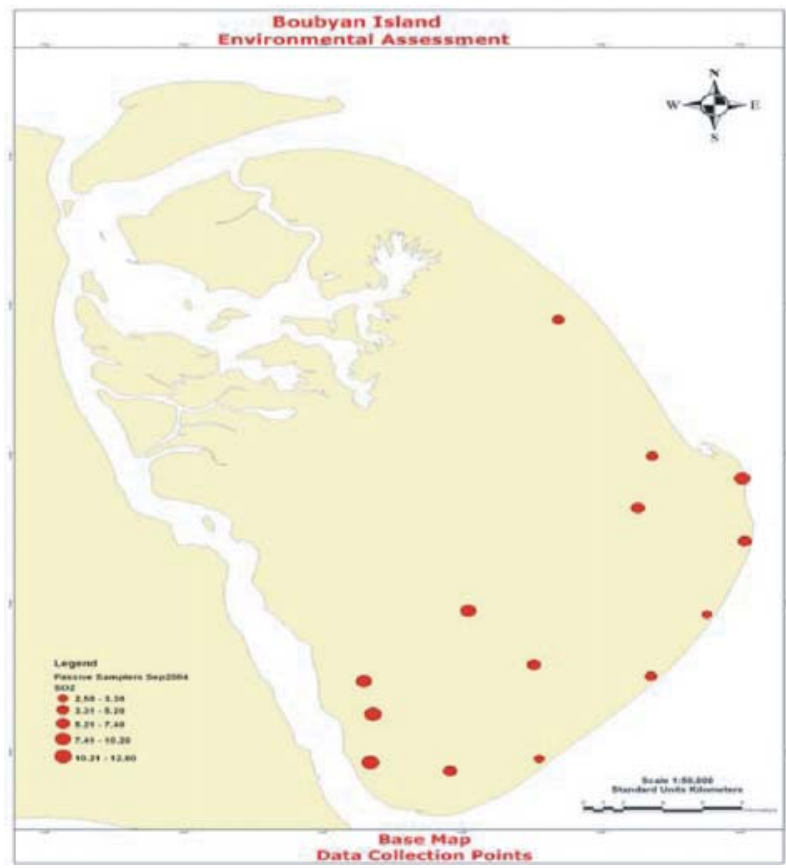

Figure 14: Air pollution concentration of $\mathrm{SO}_{2}$ for September 2004.

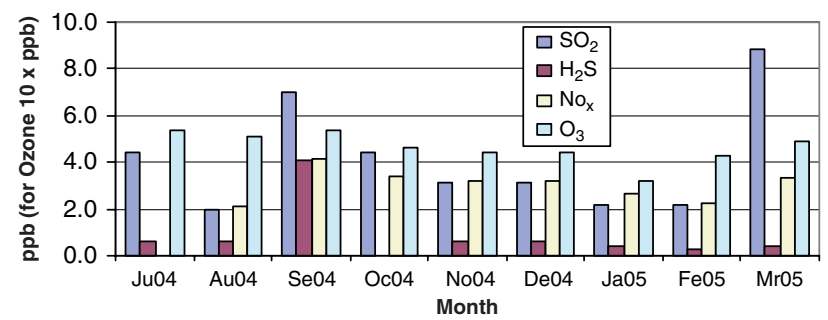

Figure 15: Monthly average concentration comparison.

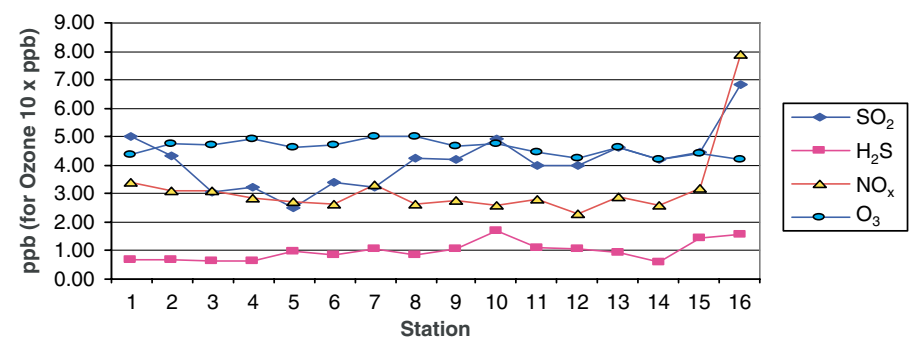

Figure 16: Nine-month average air pollution concentrations at 16 stations. 
Table 9: Nine months' average concentration of the four air pollutants for the whole network.

\begin{tabular}{lcc}
\hline Pollutant & $\begin{array}{c}\text { Ten months' } \\
\text { average in Boubyan (ppb) }\end{array}$ & $\begin{array}{c}\text { Normal background } \\
\text { concentration (ppb) }\end{array}$ \\
\hline $\mathrm{SO}_{2}$ & 4.2 & 0.2 \\
$\mathrm{H}_{2} \mathrm{~S}$ & 1.0 & 0.2 \\
$\mathrm{NO}_{\mathrm{x}}$ & 3.0 & 1 \\
$\mathrm{O}_{3}$ & 46.3 & 20 \\
\hline
\end{tabular}

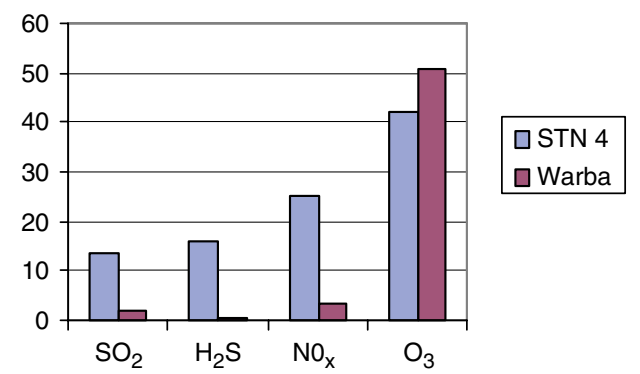

Figure 17: Air pollution concentration comparison in the industrial area (STN4) and the Boubyan Island (Warba).

This further indicates that air pollution transportation from other industrial sources does affect this area's air quality. Generally speaking, ozone concentration is controlled by NO. High NO concentrations normally result in lower ozone concentrations. Since the concentration of NO is not high in the Boubyan Island, it is not surprising that the ozone concentrations in Boubyan Island are higher than that in the industrial area.

\section{CONCLUSIONS}

The objective of this study is to conduct a baseline study for environmental conditions in Boubyan Island in order to provide information for the island's future development. The study shows that passive air pollution-monitoring network is a useful methodology to assess air quality in a relatively large area. The Boubyan Island network demonstrated the advantages of the passive samplers. The study results conclude that although the air pollution level in Boubyan Island was lower than that in a Kuwait industrial area, it was higher than the normal background concentrations in the world due to the influence of air pollution transportation from other sources. In general, the average long period concentrations of air pollutants studied in Boubyan have no significant differences except in station 16. But based on monthly results, there were differences from location to location. The study results will provide useful background information for future air quality management in Boubyan Island after it becomes economically developed.

\section{ACKNOWLEDGEMENTS}

The authors would like to express their gratitude and appreciation to the Ministry of Public Works and to Divided Zone Agreements and Kuwaiti Islands and Mega Projects Development Team for their 
support to the Boubyan Island Environmental Assessment and Preparation of a Master Plan project, and to the KISR management for their support and encouragement. The authors would also like to express their appreciation for HOK and Gulf Consults for their support and joint contribution to the project.

\section{REFERENCES}

[1] USEPA, Manual IP-9, Determination of Reactive Acidic and Basic Gases and Particulate Matter in Indoor/Outdoor Air, EPA Report No. 600/4-90-010, September 1989.

[2] Leaderer, B.P., Kotrakis, P., Wolson, J.M. \& Sullivan, J.R., Development and evaluation of a passive sampler to collect nitrous acid and sulfur dioxide. J. Expos. Environ. Epidemiol, 4, pp. 503-511, 1994.

[3] Brown, R.H., Harvey, R.P., Purnell, C.J. \& Saunders, E.G., A diffusion sampler evaluation protocol, Am. Indy. Hug. Assoc. J., 45, pp. 67-75, 1984.

[4] Singer, B.C., Hoodsport, AT., Hutchie, T. \& Kim, J., Passive measurement of nitrogen oxide to assess traffic-related pollutant exposure for the east bay children's respiratory health study. Atmospheric Environment, 38(3), pp. 393-403, 2004.

[5] Palmes, E.D. \& Gunison, A.F., Personal monitoring devices for gaseous contaminants. Am. Ind. Hyg. Assoc. J., 34, pp. 78-81, 1973.

[6] Tang, H. \& Lau, T., A new all-season passive sampling system for monitoring ozone in air. Environ. Monit. Assess, 65, pp. 129-137, 2000.

[7] Tang, H., Brassard, B., Brasssard, R. \& Peake, E., A new passive sampling system for monitoring $\mathrm{SO}_{2}$ in the atmosphere., FACT, 1(5), pp. 307-315, 1997.

[8] Tang, H., Lau, T., Brassard, B. \& Cool, W., A new all-season passive sampling system for monitoring $\mathrm{NO}_{2}$ in air. FACT, 6, pp. 338-345, 1999.

[9] Tang, H., Sandeluk, J., Lin, L. \& Lown, J.W., A new all-season passive sampling system for sampling $\mathrm{H}_{2} \mathrm{~S}$ in air. TheScientificWorld, 2, 2002.

[10] ARC (Alberta Research Council), Canada, Independent validation of Chemex (Maxxam Analytics Inc.) all season passive sampling system (CSPSS), Agreement \#JPD 003.0097, March 1998.

[11] PAMZ (Parkland Airshed Management Zone Association), www.pamz.org

[12] Tang, H., Introduction to Maxxam all-season passive sampling system and principles of proper use of passive samplers in the field study. TheScientificWorld, Vol. 1, 2001.

[13] RWDI (RWDI West Inc.), Western Canada beef productivity study, April 2001, www. rwdiwest.com

[14] Reid, P., The role of passive ambient monitoring for sulfur dioxide in the Northern Rocky Mountain foothills. Proceedings of CPAN conference, Edmonton, Canada, 14-15 April 2001.

[15] Alberta Environment Protection, Canada, Ambient air-monitoring directives, 1985. 